www.jmscr.igmpublication.org Impact Factor 5.84

Index Copernicus Value: 71.58

ISSN (e)-2347-176x ISSN (p) 2455-0450

crossref DOI: https://dx.doi.org/10.18535/jmscr/v6i1.04

\author{
Journal Of Medical Science And Clinical Research \\ IGM Publication \\ An official Publication of IGM Publication
}

\title{
RBC is most and Lymphocyte Least Commonly Effected Hematological Cell in for Acute Aluminium Phosphide Poisoning (AALPP) Patients
}

\author{
Author \\ Dr M.S. Koolwal \\ Corresponding Author \\ Dr M.S. Koolwal \\ Email- madhusudan.koolwall@gmail.com
}

\begin{abstract}
Aims \& Objectives: Exclude the EDTA induced storage artifacts .Identify and excludes the misinterpretation of peripheral blood smears examination. Identify the EDTA induced RBC \& WBC morphological storage artifacts. Identify the EDTA induced platelets related artifacts.

Material \& Methods: Blood was collected in a sterile EDTA containing tube and processed following our established laboratory protocol. A complete blood counting including $H B \%, P C V$, Red cell indices, platelet count and total white cell count and differential was done by Automated blood cell counter and peripheral blood smear examination then a sterile EDTA containing blood sample tube stored at room temperature. The all cell count indices including RBC, WBC count with differential along with morphological storage artifacts and platelet count with storages artifacts, was further confirmed by manual oil immersion smear study method. Peripheral smears study was done with field A and B stain and leishman stain.

Conclusion: EDTA cause the various storage artefacts encountered on peripheral blood smear examination when smear prepared from prolong stored sterile EDTA containing blood sample tube at room temperature. EDTA cause RBC, WBC morphological artifacts and platelets related artifacts. These artifacts lead to various misinterpretation of peripheral blood smear examination so exclude them.

Keyword: Creanated RBC, Nuclear lobe, Platelets aggregation.
\end{abstract}

\section{Material \& Methods}

Study Area and Design- - This present study was conducted at the Advanced institute of medical sciences and research Bhopal and associated referral hospital Bhopal mp. The study was designed as a observational retrograde with prospective hospital based study over a period of time from 2016.

Ethical Consideration- Blood was collected in a sterile EDTA containing tube and processed following our established laboratory protocol then generates the report of each patient. Take informed consent was obtained from all study participant for use of your blood sample for medical research after doing physician request investigating and generate the report.

Patient's Selection Criteria- The study target random selection of routine complete blood count patient. We include both OPD and IPD patients with all age groups, male and female both gender for study. Sample size is 100 patients. 
Laboratory investigations Blood was collected in a sterile EDTA containing tube and processed following our established laboratory protocol .A complete blood counting including $\mathrm{HB} \%, \mathrm{PCV}$, Red cell indices, platelet count and total white cell count and differential was done by Automated blood cell counter and peripheral blood smear examination then a sterile EDTA containing blood sample tube stored at room temperature. The all cell count indices including $\mathrm{RBC}$, WBC count with differential along with morphological storage artifacts and platelet count with storages artifacts, was further confirmed by manual oil immersion smear study method. Peripheral smears study was done with field A and B stain and leishman stain. Smear prepared from prolong stored sterile EDTA containing blood sample tube at room temperature.

\section{Complete Blood Count (CBC) and Peripheral Smear}

Materials

1. Purple vacutainer tube or capillary collector (EDTA) ethylenediaminetetraacetate

2. Slides and blue capillary tube

3. Needle or lancet

4. Vacutainer holder

5. Alcohol swab

6. Cotton balls

7. Absorbent materials

8. Slide case

\section{Procedure}

Specimen is collected into EDTA (purple) vacutainer. ( 5 or $7 \mathrm{ml}$ volume)

Preparation of peripheral blood smear from prolong stored sterile EDTA containing blood sample tube at room temperature.

Step 1. A small drop of venous blood is placed on a glass microscope slide, using a glass capillary pipette.

Step 2. A spreader slide is positioned at $45^{\circ}$ angle and slowly drawn toward the drop of blood.

Step 3. The spreader slide is brought in contact with the drop of blood and is being drawn away.

Step 4. The spreader slide is further pulled out, leaving a thin layer of blood behind.

Step 5. The blood smear is nearly complete.

Step 6. End result will be a glass slide with a wellformed blood film. After drying for about 10 minutes, the slide is fixed in methanol \& stained with field A and B stain.

A well-made peripheral smear is thick at the frosted end and becomes progressively thinner toward the opposite end. The "zone of morphology" (area of optimal thickness for light microscopic examination) should be at least $2 \mathrm{~cm}$ in length. The smear should occupy the central area of the slide and be margin-free at the edges.

Hematological examination- Hematological examination including $\mathrm{HB} \%, \mathrm{PCV}$, Red cell indices, platelet count and total white cell count with differential count should be done on peripheral smears stained with field $\mathrm{A}$ and $\mathrm{B}$ stains.

\section{Observation \& Discussion}

Organ phosphorus toxicity induced RBC changes.

\begin{tabular}{|l|c|c|c|}
\hline \multirow{2}{*}{ RBC changes } & \multirow{2}{*}{$\begin{array}{c}\text { Misinterpretation on peripheral } \\
\text { blood smears examination }\end{array}$} & \multicolumn{2}{|c|}{ Total Cases (n=100) } \\
\cline { 3 - 4 } & RBC crenations & No. & \% \\
\hline Acanthocytes & Heredity Sherocytosis & 39 & $39.00 \%$ \\
\hline Spherocytes with central pallor & Hemolytic evidence & 13 & $13.00 \%$ \\
\hline Polychromatophilic cells & Hbsc Disease & 10 & $11.00 \%$ \\
\hline Dacrocytes / Boat sheped rbc & Hemolytic Anemia & 08 & $8.00 \%$ \\
\hline Shistocytes & Liver disease & 07 & $7.00 \%$ \\
\hline Target cells & Ueaemia & 05 & $5.00 \%$ \\
\hline Echinocytes / Burr cell & High plasma protein concentration & 03 & $3.00 \%$ \\
\hline Rouleaux formation & Poor smear / store sample & 04 & $4.00 \%$ \\
\hline Degenerated erythrocytes &
\end{tabular}


WBC changes

Platelets

\begin{tabular}{|l|c|c|}
\hline WBC cells & WBC Changes & \% (n=100) \\
\hline Neutrophils & Degeneration & $44.00 \%$ \\
\hline Monocytes & Nuclear under goes disintegration. & $24.00 \%$ \\
\hline Eosinophils & Degeneration & $08 \%$ \\
\hline Lymphocyte & Dismorphism & $02 \%$ \\
\hline
\end{tabular}

\begin{tabular}{|l|l|}
\hline platelets & \% $(\mathbf{n = 1 0 0})$ \\
\hline Platelets aggregation ( Pseudo thrombocytopenia ) & $(7.00 \%)$ \\
\hline
\end{tabular}

Extended Mantel-Haenszel test for trend of chi-Squares test. Chi-sq. test X2 Value $=0.873[\mathrm{DF}=1]$ 2-sided $\mathrm{P}=0.350$ For trend in a given direction: $\mathrm{P}=0.175$

\section{Conclusion}

EDTA cause the various storage artefacts encountered on peripheral blood smear examination when smear prepared from prolong stored sterile EDTA containing blood sample tube at room temperature. EDTA cause RBC, WBC morphological artifacts and platelets related artifacts. These artifacts lead to various misinterpretation of peripheral blood smear examination so exclude them.

\section{References}

1. Lewis SM, Stoddart CT. Effects of anticoagulants and containers (glass and plastic) on the blood count. Lab Pract. 1971;10(10):787-922.

2. National Committee for Clinical Laboratory Standards. Tubes and additives for venous blood specimen collection; approved standard - fifth edition. Document H1-A5. Wayne, PA: NCCLS, 2003.

3. Lampasso JA. Error in hematocrit value produced by excessive ethylenediaminetetraacetate. Am J Clin Pathol. 1965;44 (1):109-105.

4. Rodak BF. Diagnostic Hematology. Philadelphia, PA: W. B. Saunders Company; 1995.

5. White 2nd GC, Scarborough DE, Brinkhous KM. Morphological study of early phases of platelet adhesion to foreign surfaces: effect of calcium.Ann. N.Y. Acad. Sci. 1983;416:351-62.

6. Forscher CA, Sussman II, Friedman EW, et al. Pseudothrombocytopenia masking true thrombocytopenia. Am J Hematol. 1985; 18:313-17.

7. Kjeldsberg CR, Hershgold EJ. Spurious thrombocytopenia. JAMA. 1974;227 (6):628-30.

8. Evans V. Platelet morphology and the blood smear. J Med Technol. 1984;1:689-95.

9. Shreiner DP, Bell WR. Psueudothrombocytopenia: Manifestation of a new type of platelet agglutinin. Blood. 1973;42:541-4914.

10. Reardon DM, Warner B, Trowbridge EA. EDTA, the traditional anticoagulant of haematology: with increased automation is it time for a review Med Lab Sci. 1991;48:72-75.

11. Van Assendelft OW, Parvin RM. Specimen collection, handling and storage. In: Lewis SM, Verwilghen RL, eds. Quality Assurance in haematology. London: Bailliere Tindall; 1988:5-32.

12. Lloyd E. The deterioration of leukocyte morphology with time: Its effect on the differential count. Lab Perspect 1982;1(1):13-16.

13. Gulati GL, Hyland LJ, Kocher W, Schwarting R. Automated CBC and differential result changes. Arch Pathol Lab Med. 2002:126:336-42.

14. de Baca ME, Gulati G, Kocher W, Schwarting R. Effects of storage of blood at room temperature on hematologic parameters measured on Sysmex XE2100. Lab Med. 2006;37(1):28-35.

15. International Council for Standardization 
haematology. recommendations of the international council for standardization in haematology for ethylenediaminetetraacetic acid anticoagulation of blood for blood cell counting and sizing. Am J Clin Pathol. 1993:100:371-72.

16. Gordan HG, Larson NL. Use of sequestrene as an anticoagulant.Am J Clin Pathol. 1955;23:613-18.

17. Kennedy JB, Machara KT, Baker AM. Cell and platelet stability in disodium and tripotassium EDTA. Am J Med Technol. 1981;47:89. 